\title{
Characterization of sericin protein recovered from silk wastewaters
}

\section{Ipek atıksularından geri kazanılan serisin proteininin karakterizasyonu}

\author{
Gökșen ÇAPAR ${ }^{1}, \quad$ Seylan Saniye AYGÜN²
}

\begin{abstract}
Objective: This study aims to determine the characteristics of sericin protein recovered from silk wastewaters.

Method: Sericin protein was recovered from silk wastewaters by membrane technology in Engineering Sciences Department of the Middle East Technical University between 2007 and 2008. The protein characterization study was completed in Ankara University Water Management Institute in 2012. The recovered protein was characterized in terms of molecular weight, moisture and ash contents, elemental and amino acid compositions. Dialysis was adopted to purify the protein. Sericin was extracted from native cocoons via hydrothermal processing. The solubility of recovered sericin samples at various $\mathrm{pH}$ values was determined. 2-D gel electrophoresis and MALDI-TOF analyses were used for protein identification.
\end{abstract}

Results: The molecular weight range of recovered sericin was found as 40-176 kDa, with 86-96 kDa at the highest fraction of $79-97 \%$. The recovered sericin was classifed as high-molecular weight sericin, which is suitable for making biomaterials and membranes. Moisture and ash contents were found as; $2.8-3.9 \%$ and 11.3-14.4\%. In terms of elemental composition, $\mathrm{C}, \mathrm{H}$, $\mathrm{N}$ contents of recovered sericin were determined as; $36.7-45.3 \%, 5.4-8.8 \%$ and $10.2-16.8 \%$, respectively. Properties of recovered sericin were quite similar to the reference sericin used in this study and those reported

\section{ÖZET}

Amaç: Bu çalışmanın amacı, ipek atıksularından geri kazanılan serisin proteininin özelliklerini belirlemektir.

Yöntem: Orta Doğu Teknik Üniversitesi Mühendislik Bilimleri Bölümü’nde 2007-2008 yılları arasında ipek atıksuyundan membran teknolojisi ile serisin proteini geri kazanılmıștır. Protein karakterizasyon çalıșması Ankara Üniversitesi Su Yönetimi Enstitüsü'nde 2012 yılında tamamlanmıștır. Geri kazanılan protein moleküler ağırık, nem ve kül içeriği, elementel analiz ve amino asit kompozisyonu yönünden incelenmiștir. Proteinin saflaștırılması için diyaliz işlemi uygulanmıştır. Serisin kozadan hidrotermal işlemle ekstrakte edilmiștir. Geri kazanılan proteinin farklı pH değerlerinde suda çözünürlüğü belirlenmiștir. Protein tanımlanması için 2-D jel elektroforez ve MALDI-TOF analizleri kullanılmıștır.

Bulgular: Geri kazanılan serisinin molekül ağırlık aralığı 40-176 kDa olarak tespit edilmiş, en yüksek fraksiyonun ise 86-96 kDa aralığında ve \%79-97 oranında olduğu bulunmuștur. Geri kazanılan serisin, biyomalzeme ve membran yapmaya uygun olan yüksek-molekül ağırlıklı serisin olarak sınıflandırılmıștır. Nem ve kül içerikleri \%2,8-3,9\% ve \%11,3-14,4 olarak bulunmuștur. Geri kazanılan serisinin elementel kompozisyonunda, C, H, N içerikleri sırasıyla \%36,7-45,3; \%5,4-8,8 ve $\% 10,2-16,8$ olarak bulunmuștur. Geri kazanılan serisinin özellikleri, bu çalıșmada kullanılan referans serisine ve

\footnotetext{
${ }^{1}$ Ankara University, Water Management Institute, ANKARA

${ }^{2}$ Middle East Technical University, Engineering Sciences Department, ANKARA
}

İletişim/ Corresponding Author : Gökşen ÇAPAR

Ankara University, Water Management Institute, ANKARA

Tel : +903126000162 E-posta/E-mail : gcapar@ankara.edu.tr

Geliş Tarihi / Received : 12.02.2015

Kabul Tarihi / Accepted : 01.03.2015

DOI ID : 10.5505/TurkHijyen.2015.47113

Çapar G, Aygün SS. Characterization of sericin protein recovered from silk wastewaters. Turk Hij Den Biyol Derg, 2015; 72(3): $219-34$. 
in literature. Solution $\mathrm{pH}$ significantly influenced the solubility of recovered sericin, so ethanol was observed to be a better precipitation agent than the acids used. Although some amino acids were lost during processing, the amino acid composition was acceptable. Sericin recovered from silk wastewater, with a serine content of $28.9 \%$, had the potential of high moisture absorption.

Conclusion: Sericin recovered from silk wastewaters is a promising raw material for potential applications in biomedical, cosmetics and pharmaceutical industries.

Key Words: Amino acid, molecular weight, sericin, silk, recovery literatürde yer alan diğer serisin örneklerine oldukça benzer çıkmıştır. Çözelti pH’sı, geri kazanılan serisinin suda çözünürlüğünü belirgin bir derecede etkilemiş; bu nedenle etanolün, asitlere kıyasla daha uygun bir çökeltme ajanı olduğu gözlenmiștir. Bazı amino asitler uygulanan ișlemler sırasında kaybedilmiş olsa da amino asit kompozisyonu kabul edilebilir bulunmuștur. İpek atıksuyundan geri kazanılan serisin, \%28,9'luk serin içeriği ile yüksek nem tutma potansiyeline sahiptir.

Sonuç: İpek atıksuyundan geri kazanılan serisin biyomedikal, kozmetik ve ilaç endüstrilerinde potansiyel uygulamalar için umut verici bir hammaddedir.

Anahtar Kelimeler: Amino asit, moleküler ağırlık, serisin, ipek, geri kazanım

\section{INTRODUCTION}

Sericin is a water soluble, globular and gummy protein secreted by the silkworm Bombyx mori in order to envelop the main silk fiber, namely fibroin, with sticky layers. In this way, the thin fibroin fibers are held together and the cocoon is formed. Sericin constitutes about $20-30 \%$ of the total cocoon weight (1). In textile industry, sericin is removed from the silk fiber and conventionally discharged together with silk processing wastewaters. These effluents cause severe environmental pollution in receiving water bodies due to their rich organic contents (2). However, sericin is a valuable protein with an economical value and it has a variety of end-uses in cosmetics, pharmaceutical and biomedical industries. The value of sericin on the global market varies with respect to its purity and purpose of use. For example, sericin suitable for cosmetics industry costs $€ 40-120$ per $\mathrm{kg}$. On the other hand, pure sericin that is suitable for cell culture studies costs as high as $€ 70$ per g. In recent years, investigations on sericin recovery from silk effluents have increased in view of promising research findings related to its useful properties such as antioxidation, UV resistance, moisture absorption and biocompatibility (3-4).
The annual production of silk cocoons is reported as 600.000 tons, from which 150.000 tons of sericin can be recovered (5). In Turkey, cocoon production has decreased dramatically since 1980s, however the current annual potential of sericin recovery is estimated as 13 tons approximately. These figures clearly show that sericin can provide significant economical benefits, if recovered from waste streams properly.

The recovery of a material from a waste stream requires that its properties are known and compatible with its original state so that it can be used safely. In this regard, characterization of sericin is very important for effective end-use of this protein. The characteristics of sericin obtained directly from the cocoon are well known (5-12). However, the properties of sericin recovered from textile effluents need to be determined (13-15). Recovered sericin can be used as a raw material in industries such as biotechnology and textile $(16,17)$.

Sericin can be recovered with different techniques such as precipitation in alcohol, enzymatic hydrolysis, freeze- and tray-drying and membrane filtration (2, $13,15,18,19)$. As the method of recovery influences 
the properties of the final product to a great extent, there is a need to determine the characteristics of recovered sericin so that its suitability for the target end-use can be assessed correctly. For example, molecular weight (MW) of sericin is affected by the factors such as temperature, $\mathrm{pH}$ and processing time. High MW sericin (greater than $20 \mathrm{kDa}$ ) is reported as suitable for making biomaterials and membranes, whereas low MW sericin (less than $20 \mathrm{kDa}$ ) is suitable for cosmetics, skincare products and medications (3).

In literature, there seems to exist very few studies on the characterization of sericin recovered from wastewaters. To this end, this study aims to characterize the sericin protein recovered from silk wastewaters generated in cocoon cooking process of textile industry. The characterization study covers MW, $\mathrm{pH}$, moisture and ash contents, solubility, elemental composition $(\mathrm{C}, \mathrm{H}, \mathrm{N})$ and amino acid anaysis. Dialysis was also adopted to further purify the recovered protein. The properties of recovered sericin were compared with commercial and reference sericin used in our study and also with literature in order to evaluate its quality.

\section{MATERIALS and METHODS}

Extraction of sericin from native cocoons via hydrothermal processing:

Sericin was extracted from native cocoons that were obtained from the Sogut village of Bilecik city in Turkey. This sericin was called native sericin (SN) and it was used as reference for evaluating the quality of sericin recovered (SR) from cocoon cooking wastewaters. Another reference sericin, namely commercially obtained Brazilian sericin (SC) was also used for comparison. In order to obtain $\mathrm{SN}$, the cocoon shells were cut into small pieces, followed by addition of ultra pure water at a cocoon to water ratio of 1:50 $(\mathrm{w} / \mathrm{w})$. Sericin was extracted from the cocoons by hydrothermal processing where the samples were autoclaved at $120^{\circ} \mathrm{C}$. The effect of process time on sericin solubility was determined in order to adopt the optimum reaction time. Three samples were prepared, each containing $1 \mathrm{~g}$ cocoon, and autoclaved for $1 \mathrm{~h}, 2 \mathrm{~h}$ and $5 \mathrm{~h}$, respectively. The sericin solutions obtained were filtered through $1.6 \mu \mathrm{m}$ filter media (Whatman GF/A) to separate the cocoons from sericin solution. After filtration, cold ethanol was added slowly into sericin solution until a final ethanol concentration of $75 \%(\mathrm{v} / \mathrm{v})$ was obtained. The supernatant of ethanol was discarded and the settled sericin was frozen at $-80^{\circ} \mathrm{C}$. Then, it was dried in a lyophilizator to obtain powder sericin $(8,13)$.

\section{Precipitation of sericin recovered from wastewater:}

Ethanol is commonly used to precipitate sericin (6, $8,13)$. However, the volumes that would be required for a real wastewater treatment plant effluent are excessive. Sericin can also be precipitated with acids using much smaller volumes as it becomes insoluble at pH 3.8 (20). In this regard, nitric acid, hydrochloric acid, acetic acid and sulfuric acid were tested as an alternative to ethanol in an attempt to reduce chemical consumption.

Sericin was separated from cocoon cooking wastewater via membrane processes, whose details are described elsewhere (2). The $\mathrm{pH}$ of sericin concentrate obtained via nanofiltration (NF) was decreased from 6.1 to 3.8 by using acids $(0.3 \%$ $\mathrm{v} / \mathrm{v})$. Alternatively, ethanol $(75 \% \mathrm{v} / \mathrm{v})$ was used to precipitate sericin. Samples into which precipitation agent was added, were centrifuged at $3.000 \mathrm{rpm}$ for 10-20 min to obtain sericin as a pellet. The precipitated sericin was frozen and lyophilized.

\section{Molecular weight distribution of sericin:}

In order to determine molecular weight distribution of sericin, a Shimadzu Prominence Model HPLC system was used with a gel permeation chromatography (GPC) column (Nucleogel aqua $\mathrm{OH}$ 40-8) and a buffer solution containing $0.3 \mathrm{M} \mathrm{NaCl}$ and $0.05 \mathrm{M}$ phosphate. The analyses were made at $30^{\circ} \mathrm{C}$ and ultraviolet absorbances (UVA) were read at 230 
$\mathrm{nm}$. The flow rate of mobile phase was adjusted to 0.3 mLmin-1 (21). A standard protein mixture containing cytochrome c monomer (12.4 kDa), myokinase (32 $\mathrm{kDa})$, enolase $(67 \mathrm{kDa})$, lactate dehydrogenase (142 kDa) and glutamate dehydrogenase (290 kDa) (Calbiochem) was used.

Moisture, ash and organic contents of recovered sericin:

Moisture content of sericin was determined by drying samples at $100{ }^{\circ} \mathrm{C}$ for $3 \mathrm{~h}$ followed by constant weight determination. To determine the organic and inorganic (ash) contents of sericin, samples dried at $105^{\circ} \mathrm{C}$ were ignited at $600^{\circ} \mathrm{C}$ for $90 \mathrm{~min}$. To calculate the moisture content, the difference of initial and dry weights of cocoons were divided by the initial weights of cocoons.

Elemental composition of recovered sericin:

Elemental compositions of samples were determined in the Middle East Technical University Central Laboratory. The weight percents of carbon $(\mathrm{C})$, hydrogen $(\mathrm{H})$ and nitrogen $(\mathrm{N})$ elements of sericin samples were determined on a dry basis using LECO CHNS-932 elemental analyzer. In this analysis, the instrument is heated to $1.000{ }^{\circ} \mathrm{C}$ and approximately $1 \mathrm{~g}$ of sample is placed inside a silver capsule, which is dropped into the furnace, where it is completely combusted. Infrared detection is used to measure the $\mathrm{C}$ and $\mathrm{H}$, whereas $\mathrm{N}$ is measured using thermal conductivity detection.

\section{Protein solubility:}

The solubility of recovered sericin samples at various $\mathrm{pH}$ values was determined (22). Samples were poured into the centrifugation tubes and $\mathrm{pH}$ was adjusted to 3.0, 4.0, 5.0, 6.0, 7.0, 8.0, 9.0, 10.0 and 11.0 with $1 \mathrm{M} \mathrm{NaOH}$ and $1 \mathrm{M} \mathrm{HCl}$. The tubes were thoroughly shaken and centrifuged at 4.000 rpm for $10 \mathrm{~min}$. Protein contents in the original sample and in the supernatant were determined by the bichinchoninic acid (BCA) protein protocol. In this way, the $\mathrm{pH}$ at which maximum sericin solubility occurs was determined. Protein solubility was calculated using the following equation (23-24):

Solubility $(\%)=\frac{\text { Protein content of the supernatant }}{\text { Total protein content in the sample }} \times 100$

\section{Total protein analysis:}

Total protein analysis was carried out by using BCA protocol (25). It is a spectrophotometric method where copper-BCA mixture is added into the samples and these samples are incubated in water bath at $37{ }^{\circ} \mathrm{C}$ for $30 \mathrm{~min}$. Thus, in an alkaline environment, $\mathrm{Cu}^{2+}$ ion is reduced to $\mathrm{Cu}^{+}$ion as a result of the reaction of protein and copper. Then, color occurs in the samples with the composition of $\mathrm{BCA}-\mathrm{Cu}^{+}$. In total protein analysis, UVA of the samples were read at $562 \mathrm{~nm}$ by using Hitachi model spectrophotometer and total protein concentrations were determined by the calibration equation, which was developed using reference sericin, $\mathrm{SN}$.

\section{Protein identification:}

2-D gel electrophoresis and MALDI-TOF analyses were performed in Ankara University Biotechnology Institute Proteomics Laboratory. Firstly, recovered sericin sample, which was precipitated with ethanol, was passed through the ion exchange columns (anion and cation columns), which provides the separation of biomolecules relative to their charges. After passing through anion and cation columns, 2-D gel electrophoresis was performed so that all proteins in recovered sericin sample were separated in the gel according to their iso-electric points ( $\mathrm{pl}$ ) and their MWs. Then, each spot obtained in the gel was loaded into MALDI-TOF, and the spectrums of recovered sericin sample were compared with SWISS-PROT and ExPASy protein databases in order to identify sericin. 


\section{Amino acid analysis:}

Amino acid composition of sericin samples were determined by the Food Institute of Marmara Research Center (MAM), Scientific and Technological Research Council of Turkey (TUBITAK). A Shimadzu 20 Series Ultra Fast Liquid Chromatography (UFLC) with UV detection was used. The method was adopted from literature and modified by TUBITAK MAM (26-27).

\section{Dialysis:}

Recovered sericin samples were dialyzed against ultrapure water in order to increase their purities. The molecular weight cut-off (MWCO) of dialysis sacks was $3.5 \mathrm{kDa}$ (Serva). After sericin solutions were added into the dialysis sacks, the ends of sacks were closed and put into beakers filled with ultrapure water. These beakers were shaken in a water bath at $37{ }^{\circ} \mathrm{C}$ for $1-2$ days. Then, sericin solutions in the dialysis sacks were analyzed by a high performance liquid chromatography (HPLC) with the method described in Section 2.3, except that flow rate of mobile phase was adjusted to $1.0 \mathrm{mLmin}-1$.

\section{RESULTS}

Sericin yield of native cocoons and cocoon cooking wastewaters:

In order to evaluate the sericin potential of native cocoons, the amount of sericin that can be obtained from the native cocoon shells (cocoons free from dead silkworms) was determined first. The effect of hydrothermal reaction time on sericin yield and the ethanol-precipitation efficiency were determined (Table 1). As seen, sericin yield, which was determined by dividing sericin residue by the dry weight of cocoon, increased from 0.222 $\mathrm{g} / \mathrm{g}$ cocoon to $0.232 \mathrm{~g} / \mathrm{g}$ cocoon as the reaction time increased from $1 \mathrm{~h}$ to $2 \mathrm{~h}$, corresponding to $4.5 \%$ increase of sericin yield. Further increase of reaction time to $5 \mathrm{~h}$ resulted in sericin yield of $0.239 \mathrm{~g} / \mathrm{g}$ cocoon, which indicates that five-fold increase of reaction time provided $7.7 \%$ increase of sericin yield, which is slightly higher than the result obtained at $2 \mathrm{~h}$.

Ethanol precipitation efficiency was determined by dividing the weight of sericin after ethanolprecipitation + lyophilization by the sericin residue. The reaction time had little effect on the ethanol precipitation efficiency, which increased from $66 \%$ to $72 \%$ with an increase of reaction time from $1 \mathrm{~h}$ to $2 \mathrm{~h}$.

The sericin content of wastewater was also determined by quantitative analysis. Sericin concentration in cocoon cooking wastewaters (SW) sampled at different times ranged from $5043 \mathrm{mgL}-1$ to $7957 \mathrm{mgL}-1$, with an average of $6067 \mathrm{mgL}-1$.

Table 1. Effect of hydrothermal reaction time on sericin yield and extraction efficiency

\begin{tabular}{|c|c|c|c|}
\hline \multirow{2}{*}{ Parameter } & \multicolumn{3}{|c|}{$\begin{array}{l}\text { Measured/calculated } \\
\text { value }\end{array}$} \\
\hline & $t=1 h$ & $\mathrm{t}=2 \mathrm{~h}$ & $\mathrm{t}=5 \mathrm{~h}$ \\
\hline Initial weight of cocoon (g) & 1 & 1 & 1 \\
\hline Dry weight of cocoon (g) & 0.922 & 0.922 & 0.924 \\
\hline Moisture content (\%) & 8.5 & 8.5 & 8.2 \\
\hline $\begin{array}{l}\text { Dry weight of cocoon after } \\
\text { hydrothermal processing }(\mathrm{g})\end{array}$ & 0.717 & 0.708 & 0.703 \\
\hline Sericin residue $(\mathrm{g})$ & 0.205 & 0.214 & 0.221 \\
\hline Sericin yield (g/g cocoon) & 0.222 & 0.232 & 0.239 \\
\hline $\begin{array}{l}\text { Weight of sericin after ethanol- } \\
\text { precipitation + lyophilization (g) }\end{array}$ & 0.135 & 0.154 & - \\
\hline Precipitation efficiency (\%) & 65.9 & 72.0 & - \\
\hline Overall extraction efficiency (\%) & 14.6 & 16.7 & - \\
\hline
\end{tabular}

Molecular weight distribution of sericin:

In this study, MW was determined as $138 \mathrm{kDa}$ and $124 \mathrm{kDa}$ for commercial sericin (SC) and reference sericin (SN), respectively (Figure 1a-b). In the source wastewater, four MW fractions of sericin were 
detected, which ranged from $10 \mathrm{kDa}$ to $200 \mathrm{kDa}$ at varying proportions (Figure 1c). They were named as SW1 (average MW $188 \mathrm{kDa}$, average fraction $15 \%$ ), SW2 (average MW $80 \mathrm{kDa}$, average fraction 62\%), SW3 (average MW $35 \mathrm{kDa}$, average fraction 6\% and SW4 (average MW $18 \mathrm{kDa}$, average fraction $17 \%$ (Figure 2). On the other hand, only S2 (average MW $80 \mathrm{kDa}$, average fraction 100\%) was detected in the recovered powder (Fig. 1d). This sample was obtained by adopting a process train consisting of nanofiltration+precipitation (NF+P) (28).

Since the source wastewater contained several silkworm proteins other than sericin, the final product also contained some impurities due to inadequate separation performance of the membrane technology adopted (28). This impurity, which is shown in Figure 1d, was identified as Actin cytoplasmic A3 protein at a ratio of $7.1 \%$, and sericin constituted the remaining 92.9\% of the protein powder (28). In order to further purify the protein powder, dialysis (D) was applied after NF+P process train, where precipitation of samples were carried out using different acids and ethanol. In samples obtained via NF+P+D process train, S2 (average MW $80 \mathrm{kDa}$, average fraction 80\%) and S3 (average MW $44 \mathrm{kDa}$, average fraction 20\%) were detected (Figure 1e).

The effect of dialysis step on the MW distribution of sericin is depicted in Figure 3. As seen, three different molecular weight ranges were found; S1 with MW of 151-176 kDa at a percentage of $0-12 \%$, S2 with MW of $86-96 \mathrm{kDa}$ at a percentage of $79-97 \%$, and S3 with MW of $40-44 \mathrm{kDa}$ at a percentage of $1-20 \%$, respectively. Like in the source wastewater, S2 was the dominant sericin fraction in the recovered dialysed samples. All acids and ethanol gave almost same results with respect to $\mathrm{MW}$ distribution, except that S1 (biggest sericin polypeptides) was not detected in ethanol-precipitated sample. In terms of MW, the difference between dialysed and nondialysed sericin samples was the loss of S4 (smallest sericin polypeptides having MW of $10-25 \mathrm{kDa}$ ). Although the reported MWCO of the dialysis sack was
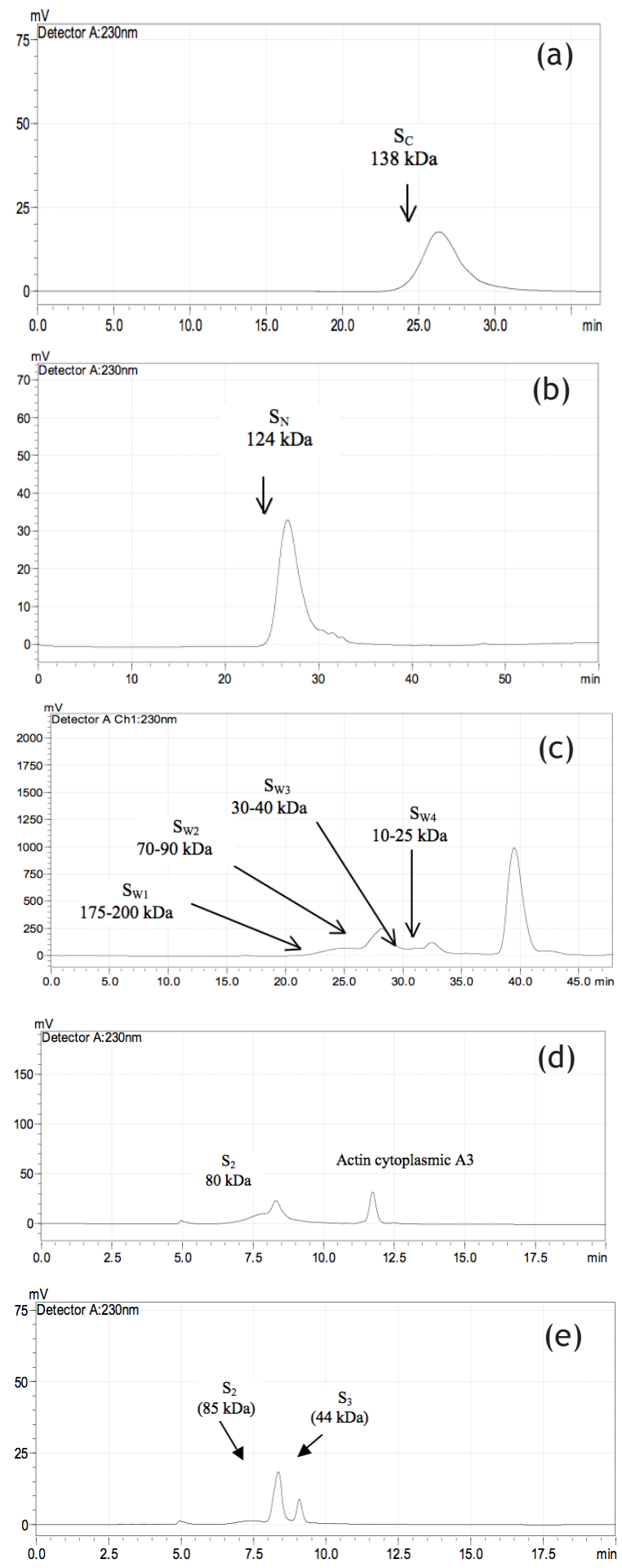

Figure 1. Molecular weight distribution of sericin in different samples
$\begin{array}{ll}\text { (a) } \mathrm{S}_{\mathrm{C}} & \text { (b) } \mathrm{S}_{\mathrm{N}}\end{array}$
(c) $\mathrm{S}_{\mathrm{w}}$
(d) $S_{R}$
(e) $S_{R D}$ 
Table 2. MW comparison of sericin with literature

\begin{tabular}{|c|c|c|c|c|c|c|c|}
\hline \multicolumn{4}{|c|}{$\begin{array}{c}M W(\mathrm{kDa}) \\
\text { reported in literature }\end{array}$} & \multicolumn{4}{|c|}{$\begin{array}{c}M W(\mathrm{kDa}) \\
\text { determined in this study }\end{array}$} \\
\hline (3) & (11) & (13) & (30) & $\mathrm{S}_{\mathrm{C}}$ & $\mathrm{S}_{\mathrm{N}}$ & $\mathrm{S}_{\mathrm{w}}$ & $S_{R}-S_{R D}$ \\
\hline $10-300$ & $24-400$ & $14-467$ & $6-15$ & 138 & 124 & $10-200$ & $40-176$ \\
\hline
\end{tabular}

much smaller $(3.5 \mathrm{kDa})$ than the $\mathrm{MW}$ of $\mathrm{S} 4$, it readily passed to the other side of the dialysis sack. This was attributed to possible degradation of S4 into much smaller peptides during dialysis since the protein is sensitive to operating temperature.

Moisture, ash and organic contents of sericin:

The $\mathrm{pH}$, moisture, ash and organic contents of reference and recovered sericin samples were determined. As seen from Table 3, the $\mathrm{pH}$ of SN was measured as 7.1. On the other hand, the $\mathrm{pH}$ of $\mathrm{SC}$ was

Table 3. Comparison of $\mathrm{pH}$, moisture and ash contents of sericin with literature

\begin{tabular}{|c|c|c|c|c|c|c|}
\hline \multirow{2}{*}{ Parameter } & \multicolumn{3}{|c|}{ Literature } & \multicolumn{3}{|c|}{ This study } \\
\hline & (3) & (13) & (30) & $\mathrm{S}_{\mathrm{C}}$ & $S_{N}$ & $S_{R}$ \\
\hline $\mathrm{pH}$ & - & 7 & $5-7$ & 3.9 & 7.1 & $4.1-7.7$ \\
\hline Moisture (\%) & $8.2-9.0$ & - & $\leq 5$ & 7.4 & 8.6 & $2.8-3.9$ \\
\hline Ash (\%) & $0.9-1.0$ & 4.2 & $\leq 4$ & 2.7 & 3.8 & $11.3-14.4$ \\
\hline
\end{tabular}

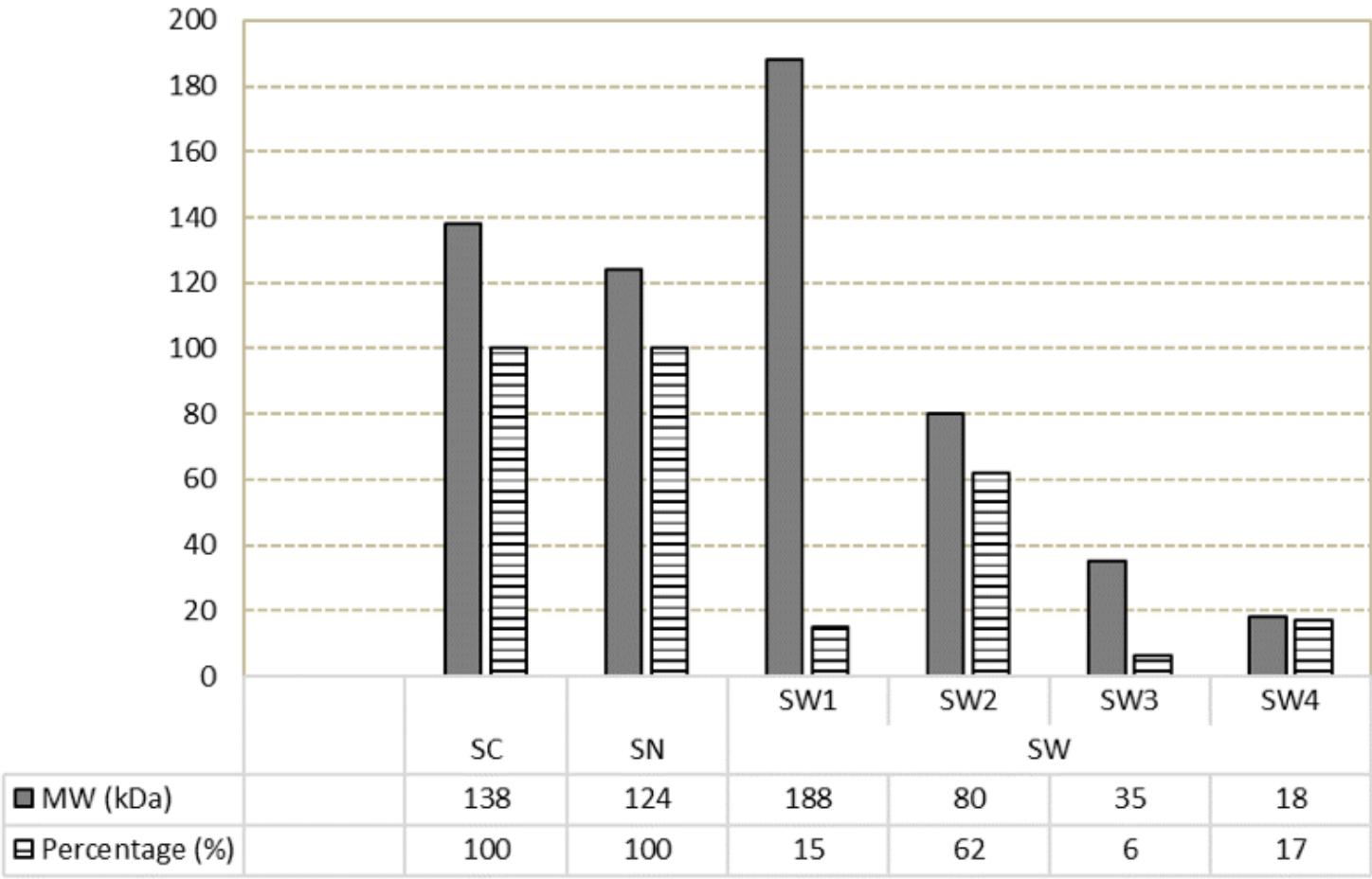

Figure 2. Average $M W$ fractions of sericin in source wastewater $\left(S_{W}\right)$ 
measured as 3.9. The $\mathrm{pH}$ of recovered sericin varied from 4.1 to 7.7 , where sericin precipitated with acids had acidic $\mathrm{pH}$ and that precipitated with ethanol had neutral $\mathrm{pH}$. Among the acids used, nitric acid and sulfuric acid resulted in the lowest and highest $\mathrm{pH}$ values of 4.1 and 5.5, respectively (Figure 4).

The moisture contents of SC and SN were found as; $7.4 \%$ and $8.6 \%$, respectively. On the other hand, the moisture content of recovered sericin changed between 2.8\% and 3.9\% (Table 3).

The ash contents of SC and SN were determined as; $2.7 \%$ and $3.8 \%$, respectively (Table 3 ). On the other hand, the ash content of recovered sericin was determined as; $11.3-14.4 \%$, where the lowest and highest values were obtained with nitric acid and ethanol, respectively (Figure 4). Among the acids used, sulfuric acid resulted in an ash content of 13.9, which was nearest to the ash content obtained by ethanol.

\section{Identification of recovered sericin:}

The 2-D electrophoresis and MALDI-TOF spectrums of protein spots revealed that recovered protein was compatible with SER1 (096614) and SER2 (096615). The pl of sericin was found as 5.9 for Sericin 1 and 4.8 for Isoform $1 \mathrm{~A}$ of Sericin 1 (with accession number of P07856-2), where the latter lost during ethanol precipitation. The pictures of reference and recovered sericin samples are depicted in Figure 5. As seen, the color of sericin recovered with acid was brown whereas that of sericin recovered with ethanol was cream and the appearance was closer to that of reference sericin.

\section{Elemental composition of sericin:}

The elemental compositions of sericin samples are given in Figure 6 and comparison with literature is given in Table 4. As seen from Figure 6, carbon contents of commercial and reference sericin were $42.5 \%$ and $41 \%$. On the other hand, carbon content of

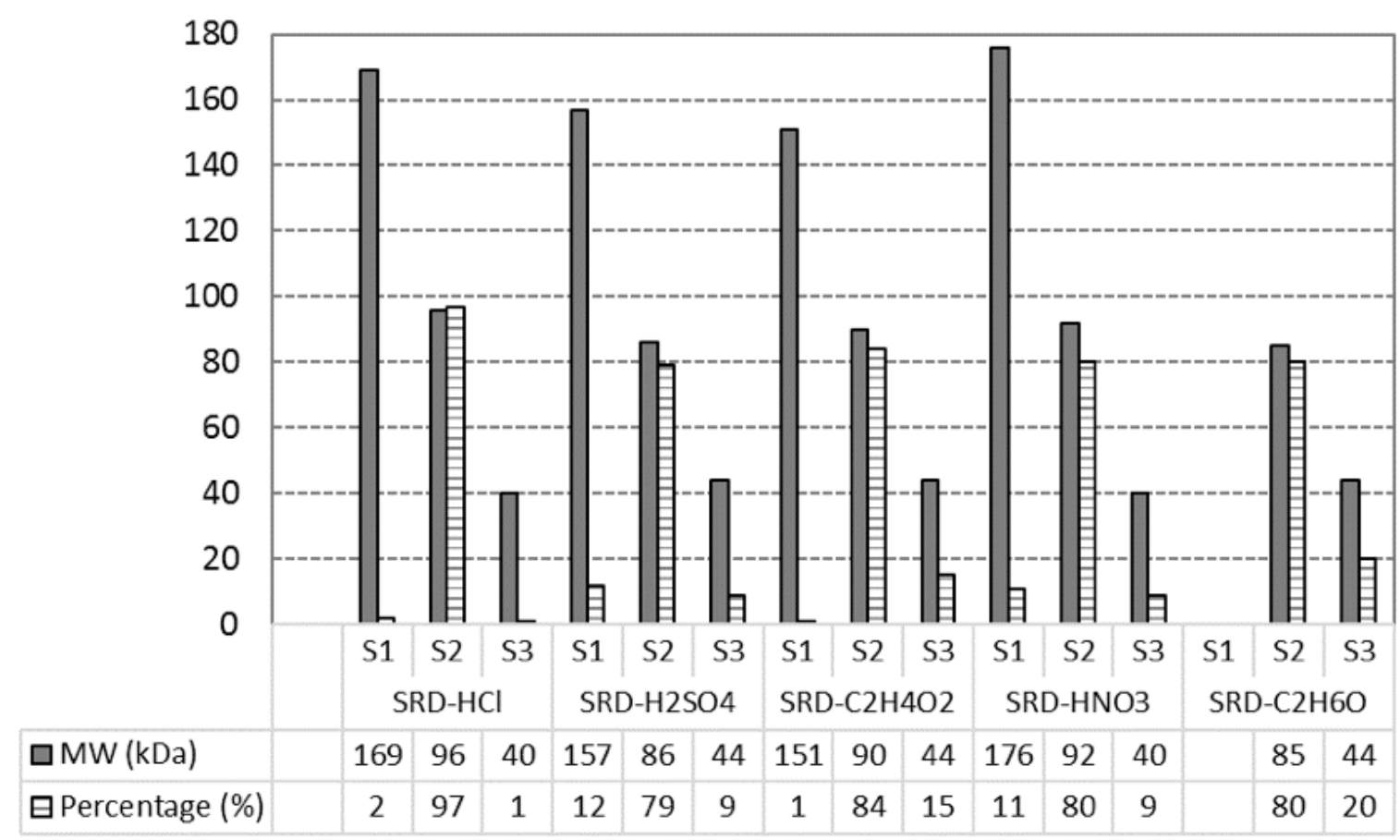

Figure 3. MW fractions of sericin samples precipitated with acids and ethanol prior to dialysis (SRD- $\mathrm{HCl}$ : recovered sericin precipitated with $\mathrm{HCl}$ and dialysed) 


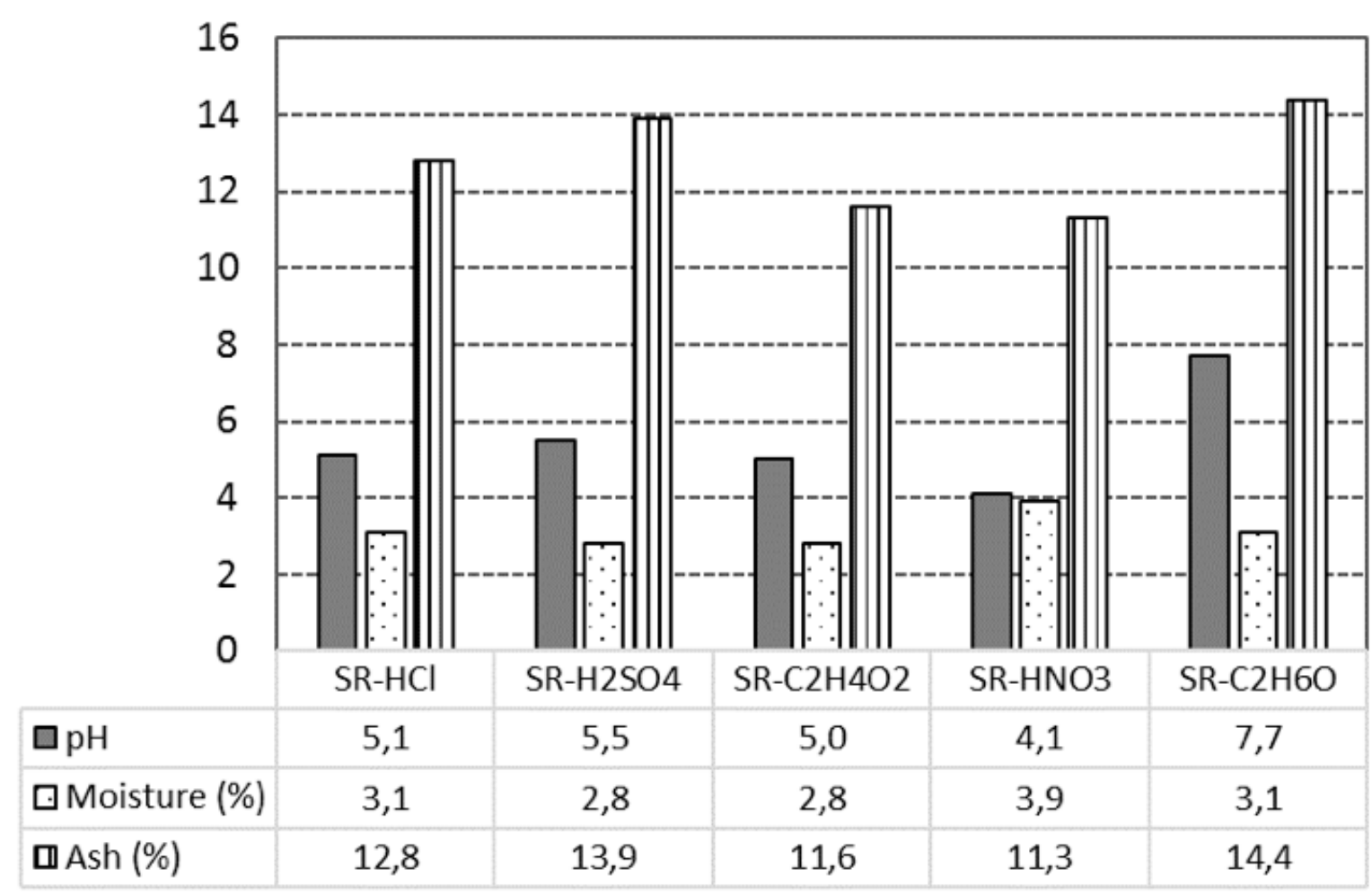

Figure 4. Effect of precipitation agent on $\mathrm{pH}$, moisture and ash content of recovered sericin

recovered sericin was slightly lower. It changed from $36.7 \%$ to $40.3 \%$, where the lowest value was obtained with nitric acid precipitation and the highest value was obtained with acetic acid precipitation.

The hydrogen contents of SC and SN were $6.4 \%$ and $6.2 \%$, respectively (Figure 6). $\mathrm{H}$ content of samples increased up to $7.3 \%-8.8 \%$ after dialysis. Regarding the nitrogen contents, $\mathrm{N}$ was determined as $13.9 \%$ and $14.9 \%$ for SC and SN, respectively. On the other hand, recovered sericin samples had lower $\mathrm{N}$ contents, i.e., 10.2-12.9\%. The highest $\mathrm{N}$ content belonged to sericin precipitated with $\mathrm{HNO}$, where additional $\mathrm{N}$ most probably originated from nitric acid. On the other hand, dialysed samples had higher $\mathrm{N}$ contents, i.e., $14.4 \%$ - 16.8\% (Table 4).

In general, elemental composition of SC and SN were almost the same, with a total $\mathrm{C}+\mathrm{H}+\mathrm{N}$ content of $62.1 \%-62.8 \%$. The remaining portion was attributed to the presence of oxygen mainly, as seen from the molecular formula of sericin (Figure 7) (34). Although recovered sericin, regardless of the precipitation agent used, had lower $\mathrm{C}+\mathrm{H}+\mathrm{N}$ content of $53.4 \%$ - 56.5\%, the dialysed samples had higher $\mathrm{C}+\mathrm{H}+\mathrm{N}$ content of $64.8 \%-70.9 \%$, where the data closest to the standards used in this study and those reported in literature, were obtained by ethanol-precipitation.

Table 4. Comparison of elemental composition of recovered sericin with literature

\begin{tabular}{|c|c|c|c|c|c|c|}
\hline \multirow{2}{*}{$\begin{array}{l}\text { Elemental } \\
\text { composition }\end{array}$} & \multicolumn{3}{|c|}{ Literature } & \multicolumn{3}{|c|}{ This study } \\
\hline & (13) & (30) & (33) & $\mathrm{s}_{\mathrm{C}}$ & $S_{N}$ & $S_{R}-S_{R D}$ \\
\hline C (\%) & & & 48.3 & 42.5 & 41.0 & $36.7-45.3$ \\
\hline H (\%) & & & 4.5 & 6.4 & 6.2 & $5.4-8.8$ \\
\hline$N(\%)$ & 14.7 & $\geq 14$ & 11.9 & 13.9 & 14.9 & $10.2-16.8$ \\
\hline
\end{tabular}



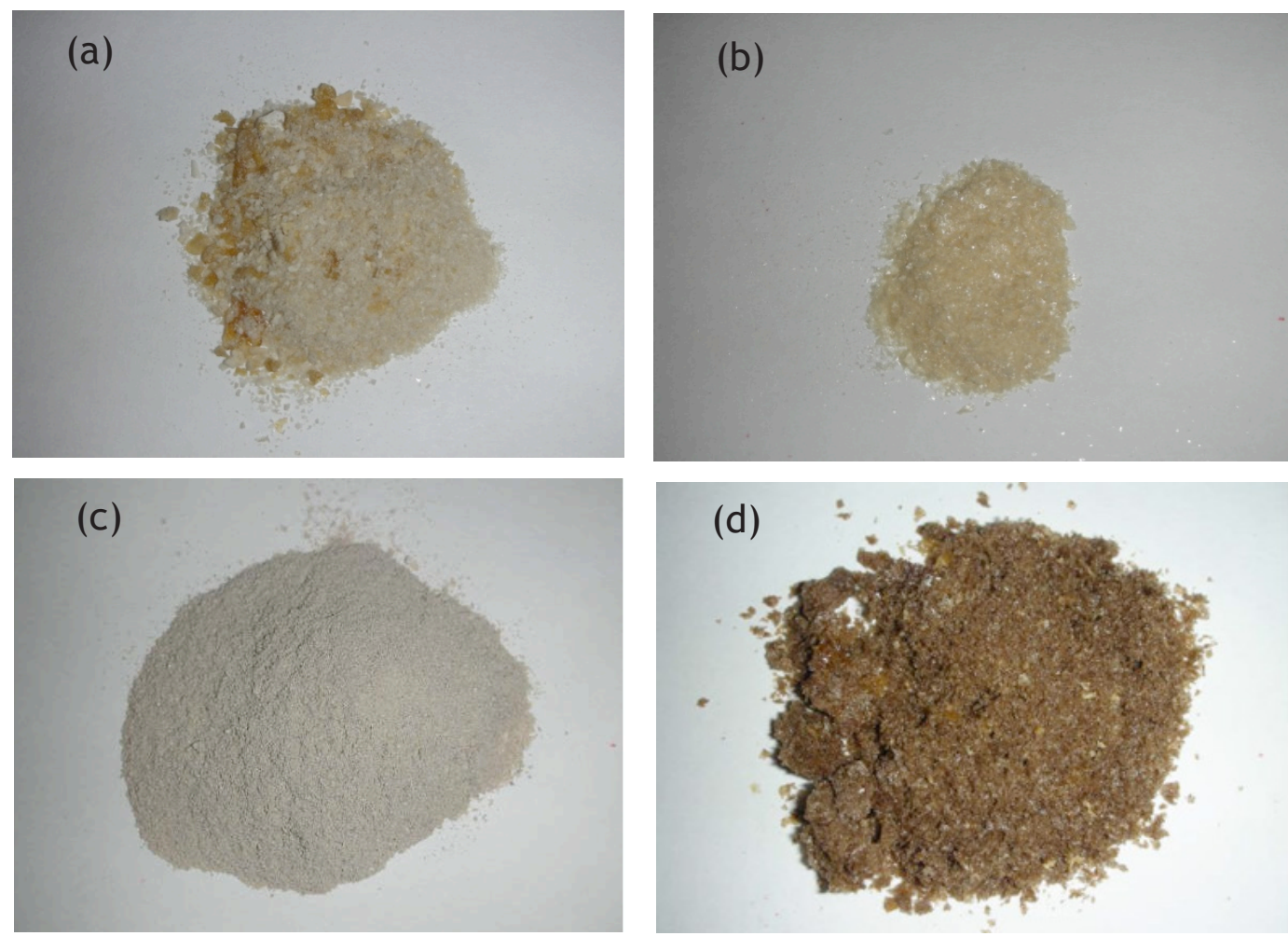

Figure 5. Pictures of (a) $S_{N}$ (unground) (b) $S_{C}$ (c) $S_{R}$ (with ethanol) (d) $S_{R}$ (with acid-HCl)

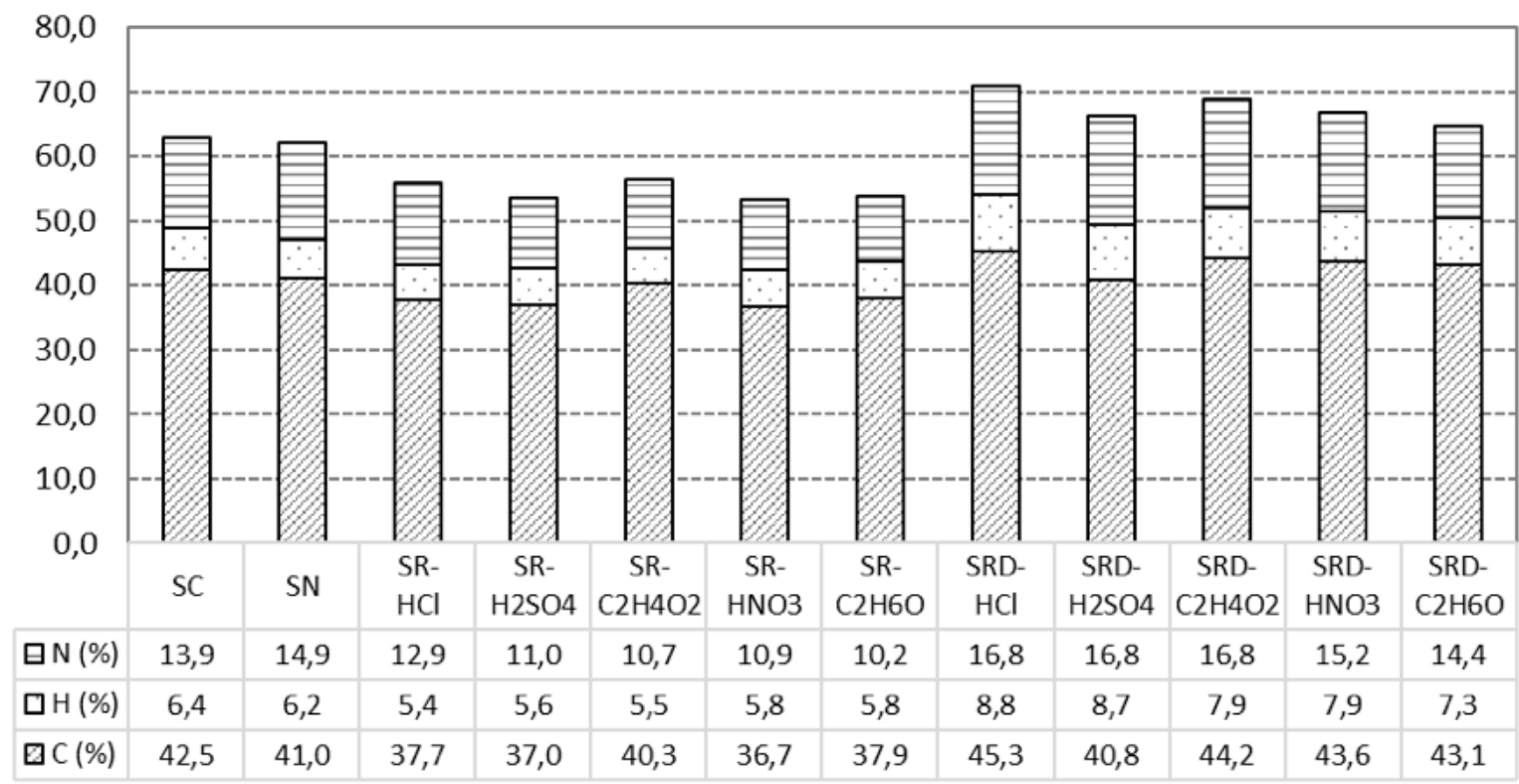

Figure 6. Elemental composition (dry basis) sericin 
<smiles>[R]C(N)C(=O)NC([R])C(=O)N([2H])C([R])C(=O)N[C@H]([R])C(=O)O</smiles>

Figure 7. Structure of sericin polypeptide (34)

\section{UV Absorbance of sericin:}

The UV absorbance spectrum of reference and recovered sericin samples were determined by wavelength scanning from $220 \mathrm{~nm}$ to $300 \mathrm{~nm}$ (Figure 8). As shown, the maximal absorption wavelength was around $220 \mathrm{~nm}$ for all sericin samples, which is attributed to the absorbance by the peptide bonds. On the other hand, only the reference sericin SN showed another distinct peak at $\lambda=275 \mathrm{~nm}$, which is assigned to the aromatic amino acids absorption wavelength (13).

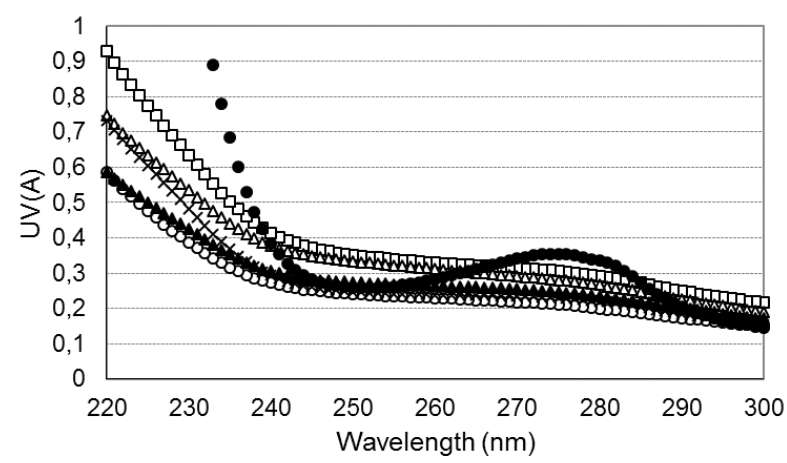

$\circ \mathrm{HNO} 3 \square \mathrm{HCl} \Delta \mathrm{H} 2 \mathrm{SO} 4 \times \mathrm{C} 2 \mathrm{H} 4 \mathrm{O} 2 \Delta \mathrm{C} 2 \mathrm{H} 6 \mathrm{O} \bullet$ Reference

Figure 8. UV absorption spectrum of recovered (SR) and reference $(\mathrm{SN})$ sericin

\section{Amino acid composition of sericin:}

Serine, aspartic acid and glycine content of commercial sericin and recovered sericin samples were determined as $56.22 \%$ and $48.86 \%$, respectively (Table 5). Serine is the dominant amino acid in sericin, which was determined as $35.3 \%$ and $28.9 \%$ for SC and SR, respectively.

\section{Solubility of recovered sericin:}

As seen from Figure 9, solubility of sericin precipitated with acids was only $47-65 \%$ at $\mathrm{pH} 3$, which increased to $59-88 \%$ at $\mathrm{pH} 7$. The solubility of sericin increased for all the acids used when $\mathrm{pH}$ was increased from 3 to 11 , where it reached $89-110 \%$ at $\mathrm{pH} 11$. On the other hand, solubility of sericin precipitated with ethanol was above $90 \%$ at all $\mathrm{pH}$ values. The reason for the solubility values which are above $100 \%$ may be that alkaline conditions enhance protein solubility.

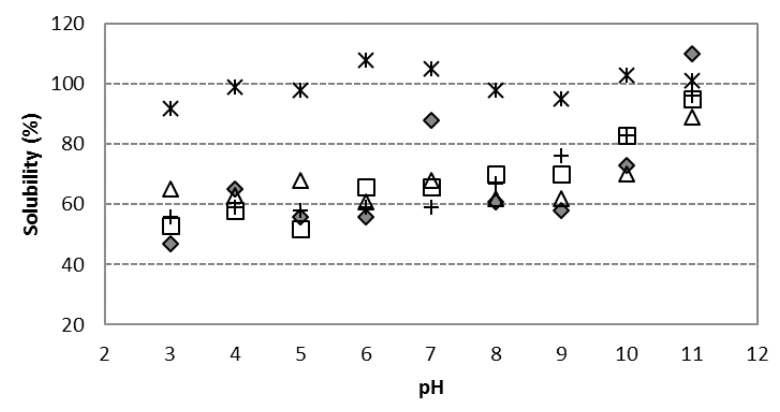

$\diamond \mathrm{HNO} \quad \square \mathrm{HCl} \quad \Delta \mathrm{H}_{2} \mathrm{SO} 4+\mathrm{C} 2 \mathrm{H} 4 \mathrm{O} 2 * \mathrm{C} 2 \mathrm{H} 6 \mathrm{O}$

Figure 9. Effect of $\mathrm{pH}$ on the solubility of recovered sericin

\section{DISCUSSION}

The overall extraction efficiency of sericin from the native cocoon, which was determined by dividing the weight of sericin after ethanol-precipitation + lyophilization by the dry weight of cocoon, slightly increased from $14.6 \%$ to $16.7 \%$ as the time was increased from $1 \mathrm{~h}$ to $2 \mathrm{~h}$. The water extraction efficiencies of sericin well agree with $14.3 \%$ reported in literature (29). Hence, it was decided to adopt a reaction time of $1 \mathrm{~h}$ throughout the study.

On the average $6 \mathrm{~g}$ of sericin could be obtained per liter of wastewater. Since sericulture is a seasonal activity in Turkey, cocoon cooking process is performed for about 80 days in a year, generating a total volume of $150 \mathrm{~m}^{3}$ of wastewater annually. This amount of wastewater would potentially yield 900 $\mathrm{kg}$ of sericin per year. A detailed research, which is 
beyond the scope of this study, is required in order to determine the potential demand for sericin on local or global market.

In literature, sericin is reported as a family of proteins with a wide range of $\mathrm{MW}$, i.e., 6-467 $\mathrm{kDa}$ $(3,11,13,30)$. This is due to the fact that molecular weight of sericin is affected by the factors such as $\mathrm{pH}$, temperature and processing time (3). The $\mathrm{MW}$ fractions of recovered sericin were classified as high $M W$-sericin, which are suitable for making biomaterials and membranes (3). A comparison with literature revealed that $M W$ of sericin varies significantly. The MW of sericin may be as low as $6 \mathrm{kDa}$ or as high as
$467 \mathrm{kDa}$ based on the processing conditions (13, 30). This was well verified in this study; the range of sericin $\mathrm{MW}$ in the source wastewater changed from $10 \mathrm{kDa}$ to $200 \mathrm{kDa}$, however it had a narrower range, which changed from $40 \mathrm{kDa}$ to $176 \mathrm{kDa}$ in the recovered samples (Table 2 ). This means the smallest and largest polypeptides were lost during processing. Nevertheless, S2 was the dominant fraction in both source wastewater and the recovered samples.

The reason for recovered sericin having moisture contents lower than those of native (SN) and commercial sericin (SC) was attributed to possible loss of some amino acids during processing, which

Table 5. Comparison of amino acid compositions of sericin with literature

\begin{tabular}{|c|c|c|c|c|c|}
\hline \multirow{2}{*}{ Amino acid } & \multicolumn{3}{|c|}{ Literature (\%) } & \multicolumn{2}{|c|}{ This study (\%) } \\
\hline & (36) & (37) & (6) & $\mathrm{S}_{\mathrm{C}}$ & $S_{R}$ \\
\hline Aspartic acid (Asp) & 14.11 & 15.64 & 13.30 & 12.25 & 10.84 \\
\hline Threonine (Thr) & 6.31 & 8.16 & 3.30 & 6.23 & 8.20 \\
\hline Serine (Ser) & 21.67 & 33.63 & 39.00 & 35.33 & 28.97 \\
\hline Glutamic acid (Glu) & 9.83 & 4.61 & 12.80 & 3.83 & 8.65 \\
\hline Glycine (Gly) & 15.26 & 15.03 & 14.30 & 8.64 & 9.05 \\
\hline Alanine (Ala) & 10.20 & 4.10 & 5.50 & 2.03 & 1.25 \\
\hline Cysteine (Cys) & 0 & 0.44 & $\mathrm{nr}$ & $\mathrm{nr}$ & $\mathrm{nr}$ \\
\hline Valine (Val) & 2.76 & 2.88 & 0.70 & 3.01 & 3.09 \\
\hline Methionine (Met) & 0.53 & 3.39 & $\mathrm{nr}$ & bdl & 0.27 \\
\hline Isoleucine (Ile) & 2.60 & 0.56 & 0.20 & 0.67 & 1.21 \\
\hline Leucine (Leu) & 3.82 & 1.00 & 0.50 & 1.46 & 2.24 \\
\hline Tyrosine (Tyr) & 2.08 & 3.45 & 0.70 & 5.88 & 4.03 \\
\hline Phenylalanine (Phe) & 1.49 & 0.28 & $\mathrm{nr}$ & 0.58 & 1.25 \\
\hline Lysine (Lys) & 3.02 & 2.35 & 5.40 & 1.80 & 3.66 \\
\hline Histidine (His) & 1.55 & 1.06 & 1.00 & 2.33 & 2.79 \\
\hline Arginine (Arg) & 3.96 & 2.87 & 2.90 & 12.91 & 8.37 \\
\hline Proline (Pro) & 0.78 & 0.54 & $\mathrm{nr}$ & 2.11 & 3.81 \\
\hline cis-4-Hydroxy-D-proline (Hyp) & $\mathrm{nr}$ & $\mathrm{nr}$ & $\mathrm{nr}$ & 0.72 & 2.15 \\
\hline Tryptophan (Trp) & $\mathrm{nr}$ & $\mathrm{nr}$ & $\mathrm{nr}$ & 0.21 & 0.17 \\
\hline Total & 99.97 & 99.99 & 99.60 & 99.99 & 100.00 \\
\hline
\end{tabular}

nr: not reported, bdl: below detection limit 
play functional role in moisture absorption. This was also verified via the amino acid analysis conducted.

The $\mathrm{pH}$ of $\mathrm{SN}$, which was measured as 7.1 agrees well with the range of 5-7 reported in literature (13, 30). On the other hand, the $\mathrm{pH}$ of $\mathrm{SC}$, measured as 3.9 was lower than those reported in literature. Since $\mathrm{SN}$ was produced in our laboratory without any $\mathrm{pH}$ change, it is expected to have neutral $\mathrm{pH}$. However, the recovery method of SC is unknown as it was a commercial product obtained from abroad through a local supplier. So, the lower $\mathrm{pH}$ of SC was attributed to the recovery method applied, which was probably conducted at acidic $\mathrm{pH}$. The $\mathrm{pH}$ of recovered sericin, which varied from 4.1 to 7.7 was also similar to literature findings $(13,30)$.

The moisture contents of SC and SN were slightly higher than $\leq 5 \%$ reported by the commercial supplier (30), but quite close to $9 \%$ and $8.2 \%$ reported by Zhang (3) for cocoon and silk yarn, respectively. On the other hand, the moisture content of recovered sericin, which changed between $2.8 \%$ and $3.9 \%$ was lower than those of SC and SN, but very close to those reported by a commercial supplier (30) (Table 3).

The ash contents of SC and SN were slightly higher than the values reported in literature (3). In a study in which the thermal properties of silk fibers were examined, this content was reported as $0.9 \%$ and $1.0 \%$ after the ignition of cocoon and silk yarn, respectively, at $550{ }^{\circ} \mathrm{C}$ for one night (3). The reason for this difference may be the ignition of different materials, that is, sericin-rich protein powder was ignited in this study whereas cocoon shell made of sericin and fibroin was ignited by Zhang (3). The ash contents of sericin and fibroin may differ, resulting in different values. On the other hand, the ash contents of $\mathrm{SC}$ and $\mathrm{SN}$ were quite close to those of 3-4\% reported for pure sericin by the commercial retailer (30) and Wu et al. (13). Sericin ash possibly contained a little salt, as the inorganic content of cocoon includes calcium, potassium, sulphur, phosphorus, silicon and magnesium (31). The ash content of recovered sericin was much higher than those of SC and SN, whis means that the organic content of recovered sericin was slightly lower. This was attributed to the fact that recovered powder was a sericin-rich product rather than pure sericin so the presence of other silkworm protein in the recovered sample might have contributed to the higher ash content of recovered sericin.

The $\mathrm{pl}$ of sericin agreed with the $\mathrm{pl}$ values of 5.0 and 4.3 reported for silk fiber (32) and protein purified from the cocoon shell of silkworm (8). The color difference between sericin samples recovered with ethanol and acids was attributed to the dilution of sericin solution due to addition of ethanol at higher volumes.

Regarding the elemental compositions, the reason for lower $\mathrm{C}$ contents of recovered sericin as compared to the standards can be explained in two ways; first, the recovered powder contained another silkworm protein as an impurity, second, the processes applied in the textile industry to remove sericin from the silk fiber and the processes applied in our laboratory to recover sericin from wastewater might have caused loss of some amino acids, resulting in lower carbon contents. The dialysis results suggest that the first reason is more likely, because when dialysis was applied to purify sericin, C content of samples increased up to $40.8 \%$ - $45.3 \%$, which are closer to the $\mathrm{C}$ contents of commercial and reference sericin used in this study, as well as to the carbon content of $48.3 \%$ reported by Chen et al. (33). Comparing the precipitation agents, highest $\mathrm{C}$ content was obtained with acetic acid. The reason for this was attributed to the likely presence of additional carbon coming from acetic acid, which might have bound to the protein during precipitation.

The hydrogen content of recovered sericin was slightly lower than those of SC and SN, however it was very similar to the value of $4.5 \%$ reported Chen et al. (33). Nitrogen content of SC and SN were almost the same with $14.0 \%$ and $14.7 \%$ reported by Wu et al. (13) and a commercial retailer (30). On the other hand, recovered sericin samples had lower $\mathrm{N}$ 
contents. The highest $\mathrm{N}$ content belonged to sericin precipitated with $\mathrm{HNO} 3$, where additional $\mathrm{N}$ most probably originated from nitric acid. On the other hand, dialysed samples had higher $\mathrm{N}$ contents, i.e., $14.4 \%-16.8 \%$, which are closer to the standards and literature findings $(13,30)$.

Proteins generally have two absorbance peaks in the UV region, one between 215-230 nm, where peptide bonds absorb, and another at about $280 \mathrm{~nm}$ due to light absorption by aromatic amino acids. Similarly, the silk sericin shows a peak absorbance at around $280 \mathrm{~nm}$ of wavelength (35). The UV absorbance spectrum of reference and recovered sericin samples showed that the maximal absorption wavelength was around $220 \mathrm{~nm}$ for all sericin samples, which is attributed to the absorbance by the peptide bonds. On the other hand, only the reference sericin $\mathrm{SN}$ showed another distinct peak at $\lambda=275 \mathrm{~nm}$, which was assigned to the aromatic amino acids absorption wavelength (13). This result showed that peptide bonds were the major absorbing group for recovered sericin in the ultraviolet region, and indicates the loss of some aromatic amino acids in recovered sericin samples to some extent, as verified by amino acid analysis. This is indeed quite expected, because the proteins are subject to degradation during processing.

The amino acid composition of recovered sericin was compared with literature. There are slight differences in amino acid compositions due to different processing techniques used as well as the degradation of the protein. Serine, aspartic acid and glycine content of sericin samples reported in literature count for more than $50 \%$ of the whole amino acid composition, i.e., 51.04\%, 64.30\% and $66.60 \%$ were determined by Takasu et al. (6), Wu et al. (36) and Aramwit et al. (37). In this study, serine, aspartic acid and glycine content of commercial sericin and recovered sericin samples were determined as $56.22 \%$ and $48.86 \%$, respectively. Serine is the dominant amino acid in sericin, which was determined as $35.3 \%$ and $28.9 \%$ for SC and SR, respectively. These values are quite compatible with those reported in literature, i.e., 21.7\% (36), $33.6 \%(37)$ and $39.0 \%(6)$. These results reveal that amino acid composition of recovered sericin, despite the loss of some amino acids, is quite acceptable as compared with literature.

The results obtained for the solubility of recovered protein showed that ethanol may be better than acids for precipitation considering the end-use of recovered sericin. Sericin precipitated with acids would necessitate the adjustment of $\mathrm{pH}$ to basic conditions for achieving complete solubility. This would limit the applicability of recovered sericin in some industries or require additional processing steps. On the other hand, complete solubility of sericin recovered with ethanol at all $\mathrm{pH}$ values would provide significant benefits.

\section{CONCLUSIONS}

Sericin recovered from cocoon cooking wastewaters of textile industry was characterized in terms of $\mathrm{MW}, \mathrm{pH}$, moisture, ash, elemental analysis, amino acid analysis and protein solubility. Sericin recovered from the source wastewater had acceptable quality; where its properties were similar to the commercial and reference sericin used in this study, as well as those reported in literature. With a serine content of almost $29 \%$, recovered sericin holds the potential of high moisture absorption and is a promising raw material for potential applications in biomedical, cosmetics and pharmaceuticals industy. 


\section{ACKNOWLEDGEMENTS}

The authors gratefully acknowledge the Scientific and Technological Research Council of Turkey (TUBITAK) for the financial support via Grant No. 106 M 062 and the British Council for the financial support via Scientific Partnership Program. The authors also acknowledge Prof. Dr. Ülkü Yetiş for financing the amino acid analysis. Assoc. Prof. Dr. Duygu Demiralp is also gratefully acknowledged for performing the protein identification study.

\section{REFERENCES}

1. Masahiro S, Hideyuki Y, Norihisa K. Consumption of silk protein, sericin elevates intestinal absorption of zinc, iron, magnesium and calcium in rats. Nutr Res, 2000; 20: 1505-11.

2. Capar G, Aygun SS, Gecit MR. Treatment of silk production wastewaters by membrane processes for sericin recovery. J Membr Sci, 2008; 325: 920-31.

3. Zhang YQ. Applications of natural silk protein sericin in biomaterials. Biotechnol Adv, 2002; 20: 91-100.

4. Kato N, Sato S, Yamanaka A, Yamada H, Fuwa N, Nomura M. Silk protein, sericin, inhibits lipid peroxidation and tyrosinase activity. Biosci Biotechnol Biochem, 1998; 62: 145-7.

5. Oh H, Lee JY, Kim MK, Um IC, Lee KH. Refining hot-water extracted silk sericin by ethanol-induced precipitation. Int J Biol Macromol, 2011; 48: 32-7.

6. Takasu Y, Yamada H, Tsubouchi K. Isolation of three main components from the cocoon of the silkworm, bombyx mori. Biosci Biotechnol Biochem, 2002; 66: 2715-18.

7. Dash R, Mukherjee S, Kundu SC. Isolation, purification and characterization of silk protein sericin from cocoon peduncles of tropical tasar silkworm, Antheraea mylitta. Int J Biol Macromol, 2006; 38: 255-8.

8. Kurioka A, Kurioka F, Yamazaki M. Characterization of sericin powder prepared from citric aciddegraded sericin polypeptides of the silkworm, bombyx mori. Biosci Biotechnol Biochem, 2004; 68: 774-80.

9. Zhang YQ, Tao ML, Shen WD, Mao JP, Chen Y. Synthesis of silk sericin peptides-L-asparaginase bioconjugates and their characterization. J Chem Technol Biotechnol, 2006; 81: 136-45.
10. Dash R, Ghosh SK, Kaplan DL, Kundu SC. Purification and biochemical characterization of a $70 \mathrm{kDa}$ sericin from tropical tasar silkworm, Antheraea mylitta. Comp Biochem Physiol B Biochem Mol Biol, 2007; 147: 129-34.

11. Kundu SC, Dash BC, Dash R, Kaplan DL. Natural protective glue protein, sericin bioengineered by silkworms: Potential for biomedical and biotechnological applications. Prog Polym Sci, 2008; 33: 998-12.

12. Lamoolphak W, De-Eknamkul W, Shotipruk A. Hydrothermal production and characterization of protein and amino acids from silk waste. Bioresource Technol, 2008; 99: 7678-85.

13. Wu J, Wang $\mathrm{Z}$, Xu SY. Preparation and characterization of sericin powder extracted from silk industry wastewater. Food Chem, 2007; 103: 1255-62.

14. Wu JH, Wang Z, Xu SY. Enzymatic production of bioactive peptides from sericin recovered from silk industry wastewater. Process Biochem, 2008; 43: 480-7.

15. Vaithanomsat $P$, Kitpreechavanich V. Sericin separation from silk degumming wastewater. Sep Purif Technol, 2008; 59: 129-33.

16. Anghileri A, Lantto R, Kruus K, Arosio C, Freddi $G$. Tyrosinase catalyzed grafting of sericin peptides onto chitosan and production of proteinpolysaccharide bioconjugates. J Biotechnol, 2007; 127: 508-19.

17. Cortez J, Anghieri A, Bonner PLR, Griffin M, Freddi G. Transglutaminase mediated grafting of silk proteins onto wool fabrics leading to improved physical and mechanical properties. Enzyme Microb Technol, 2007; 40: 1698-04. 
18. Fabiani C, Pizzichini M, Spadoni M, Zeddita G. Treatment of wastewater from silk degumming processes for protein recovery and water reuse. Desalination, 1996; 105: 1-9.

19. Capar G, Aygun SS, Gecit MR. Separation of sericin from fatty acids towards its recovery from silk degumming wastewaters. J Membr Sci, 2009; 342: 179-89.

20. Kodama K. The preparation and physico-chemical properties of sericin. Biochem J, 1926; 20: 1208-22.

21. Ogino M, Tanaka R, Hattori M, Yoshida T, Yokote $Y$, Takahashi, Interfacial behavior of fatty-acylated sericin prepared by lipase-catalyzed solid phase synthesis. Biosci Biotechnol Biochem, 2006, 70: 66-75.

22. Wu U, Hettiarachchy S, Qi M. Hydrophobicity, solubility, and emulsifying properties of soy protein peptides prepared by papain modification and ultrafiltration. J Am Oil Chem Society, 1998; 75: 450-845.

23. Were L, Hettiarachchy NS, Kalapathy U. Modified soy proteins with improved foaming and water hydration properties. J Food Sci, 1997; 62: 821-3.

24. Chove BE, Grandison AS, Lewis MJ. Some functional properties of fractionated soy protein isolates obtained by microfiltration. Food Hydrocolloid, 2007; 21: 1379-88.

25. Krieg RC, Dong Y, Schwamborn K, Knuechel R. Protein quantification and its tolerance for different interfering reagents using the BCAmethod with regard to 2D SDS PAGE. J Biochem Bioph Meth, 2005; 65: 13-9.

26. Dimova N. RP-HPLC analysis of aminoacids with UVdetection. Bulg Acad Sci, 2003, 56: 75-8.

27. Gheshlaghi R, Scharer JM, Moo-Young M, Douglas PL. Application of statistical design for the optimization of aminoacids separation by reversephase HPLC. Anal Biochem, 2008; 383: 93-2.
28. Capar G. Separation of silkworm proteins in cocoon cooking wastewaters via nanofiltration: effect of solution $\mathrm{pH}$ on enrichment of sericin. J Membr Sci, 2012; 389: 509-21.

29. Tao W, Li M, Xie R. Preparation and structure of porous silk sericin materials. Macromol Mater Eng, 2005; 290: 188-94.

30. Huzhou Aotesi Biochemical, http://www.silk protein.com/silk-sericin.html, last date of access: December 2014.

31. American Society of Agricultural and Biological Engineers (ASABE), Thermal properties and inorganic composition of silk fiber. https:// elibrary. asabe. org/abstract. .asp?aid=9235\&t $=2 \&$ redir $=\&$ tredirType $=$. (last date of access: December 2014.)

32. Mondal M, Trivedy K, Kumar SN. The silk proteins, sericin and fibroin in silkworm, Bombyx mori Linn., - a review. Caspian J Environ Sci, 2007; 5: 63-76.

33. Chen X, Lam KF, Mak SF, Yeung KL. Precious metal recovery by selective adsorption using biosorbents. J Hazard Mater, 2011; 186: 902-10.

34. Morrison RT, Boyd RN. Organic Chemistry. 6th ed., Prentice Hall, 1992.

35. Kim SJ. Gas permeation through water-swollen sericin/PVA membranes. Master Thesis, University of Waterloo, Ontario, Canada, 2007.

36. Wu MH, Yue JX, Zhang YQ. Ultrafiltration recovery of sericin from the alkaline waste of silk floss processing and controlled enzymatic hydrolysis. J Clean Prod, 2014; 76: 154-60.

37. Aramwit $P$, Siritientong $T$, Kanokpanont $S$, Srichana T. Formulation and characterization of silk sericinPVA scaffold crosslinked with genipin. Int J Biol Macromol, 2010, 47: 668-75. 